\title{
COMMUNITY EMPOWERMENT EFFORTS IN PRIVATE FOREST DEVELOPMENT OF MALANG REGENCY, INDONESIA
}

\author{
Rosyidatuzzahro Anisykurlillah*, Tjahjanulin Domai, Romy Hermawan \\ Faculty of Administrative Science, University of Brawijaya, Indonesia \\ *E-mail: rosyidatuz@gmail.com
}

\begin{abstract}
This research discusses community empowerment efforts in private forest development in Malang Regency. Community empowerment efforts in the development of private forests are not optimal because there are still some obstacles, namely the lack of forestry extension workers, low community participation, and weak institutional farmer groups. The programs and activities of private forest development based on community empowerment don't fully accommodate the basic needs of the community. Community groups prefer activities such as institutional training and market access than forestry technical activities (such as nursery training, fertilizing, maintenance, etc). Planning for community forest development is formulated in a top-down approach. The community is still not involved in the planning of private forest development in Malang Regency.
\end{abstract}

\section{KEY WORDS}

Community empowerment, forestry development, private forest, participation, bottom-up approach.

Forest damage in Malang Regency doesn't only occur within state forest areas (protected forests and production forests), but also outside state forest areas. This can be seen from the amount of critical land in Malang Regency in 2017 which is 155.805 ha with the distribution of protected forest is $15.923 \mathrm{ha}$, production forest is $52.397 \mathrm{ha}$, and outside the state forest area is 87.485 ha (East Java Province Forestry Statistics Data, 2018). One of the efforts made to reduce critical land outside the state forest area is through the development of private forests. However, one of the strategic issues in forestry development is undeveloped private forests. Moreover, the private forest area in Malang Regency has decreased from 44.762 ha in 2016 to 31.909 ha in 2017 (East Java Province Forestry Statistics Data, 2018). The decrease in the area of private forest is due to land use change from forest to agricultural land.

The existence of private forests in Malang is very volatile, because it could be today is a forest, but tomorrow it is cut down and made into agricultural land, or it can happen otherwise. Community involvement is absolutely necessary in the development of private forests. Therefore, the private forest development requires a comprehensive approach through community empowerment. Narayan (2002) explains "Empowerment is the expansion of assets and capabilities of poor people to participate in, negotiate with, influence, control, and hold accountable institutions that affect their lives". Private forest development needs to be done through various programs and activities that are pro-empowering and based on environmental sustainability. Solving forestry development problems must pay attention to economic, social and environmental aspects in order to realize sustainable development.

\section{LITERATURE REVIEW}

To identify development programs and activities that are included in empowerment activities means that these activities must contain the principles of community empowerment. Community empowerment programs and activities must contain empowerment principles such as (1) Process approach (Similar to a bottom-up approach), (2) Participation, (3) Conservation and Sustainable Use, (4) Linkages, (5) Incentive Packages (or readily observed tangible benefits - social or economic) (Drijver and Sajise, 1993). Community 
empowerment as a strategy in development that is oriented towards providing opportunities to every member of the community. The essence of community empowerment is an effort to build the capacity (Capacity Building) of the community and empower existing human resources (HR) through institutional development, facility development, and development of assistance, counseling, and service (Zubaedi, 2007). Narayan (2002) mentions that there are four elements of empowerment as an effort to empower the community including (1) access to information, (2) inclusion and participation, (3) accountability, and (4) local organizational capacity.

\section{METHODS OF RESEARCH}

The type of this research is descriptive with qualitative approach. Sugiyono (2014) defines a qualitative approach is research methods used to examine natural object conditions (as opposed to experiments) where the researcher is a key instrument, data collection techniques are triangulated (combined), data analysis is inductive, and qualitative research results emphasize the meaning rather than generalization. The data collection techniques in this research are through interviews, observation and document study. Data analysis in this study uses the interactive model of Milles, Huberman and Saldana. The analysis component in the interactive model by Miles, Huberman, and Saldana (2014) consists of data condensation, data display, and verifying.

\section{RESULTS AND DISCUSSION}

Efforts to empower people in the development of private forests in Malang were implemented through programs and activities based on community empowerment. The program is a form of policy instrument that contains one or more activities implemented by government agencies. The following programs and activities in private forest development based on community empowerment formulated by Malang Regional CDK as shown below:

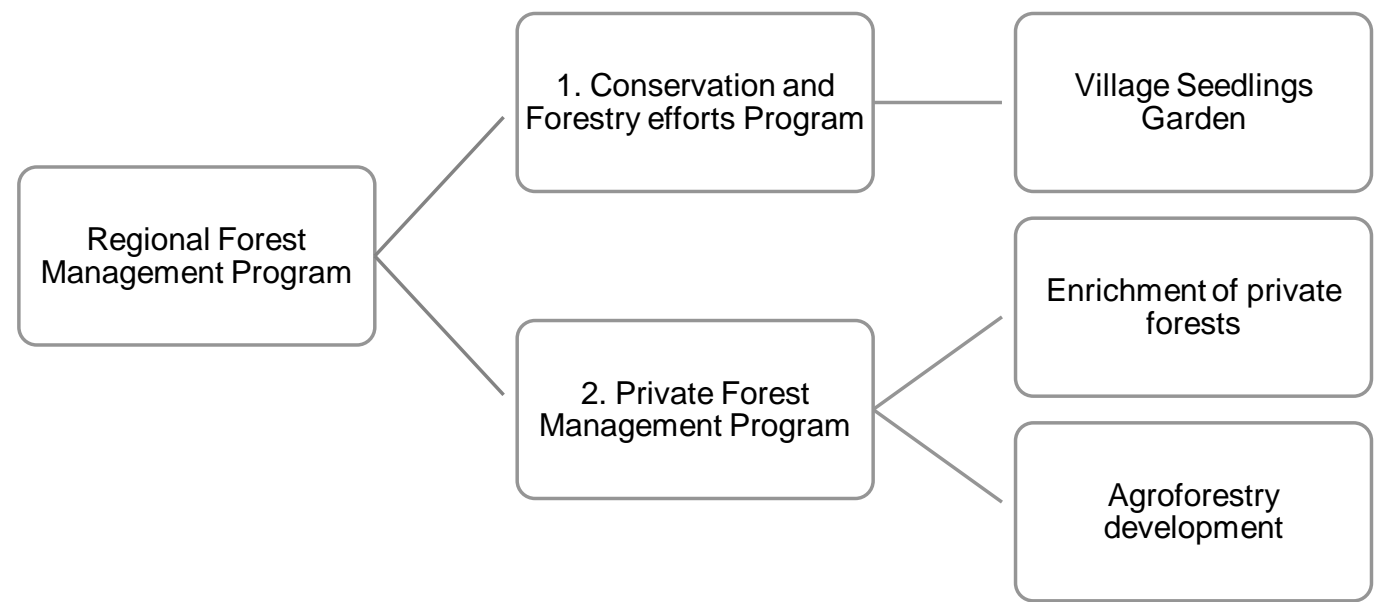

Figure 1 - Private Forest Development Program based on Community Empowerment in Malang Regional CDK Planning (Source: Data Processed)

From the picture above, in the Regional Forest Management Program consists of two programs which are distinguished by the source of funding. (1) Conservation and Forestry efforts Program is a program sourced from regional expenditure budget (APBD). This program is in the form of manufacturing activities a Village Seedlings Garden. Village Seedlings Garden is a making private forest seeds in the context of conservation and community empowerment through conservation activities and forestry efforts. The establishment of nurseries is carried out by farmer groups. The results of this nursery will be planted on critical land outside the state forest area. (2) Private Forest Management Program programs that use the special allocation fund (DAK) in the forestry sector. Enrichment of 
private forests and agroforestry development are timber planting activities to optimize land use.

The core of the community forest development program based on community empowerment is a vegetative activity (planting) by involving the community through the process of community empowerment. To identify whether the program and activities really use the approach or based on community empowerment, it can be seen from the following: (1) Process approach (Similar to a bottom-up approach), (2) Participation, (3) Conservation and Sustainable Use, (4) Linkages, (5) Incentive Packages (or readily observed tangible benefits - social or economic) (Drijver and Sajise, 1993).

Target villages for program recipients are determined top-down by the Malang Regional CDK. Determination of plant species in the activities of village seedlings garden, enrichment of private forests and agroforestry development uses priority scale by considering the technical (biophysical) aspects and community desires (socio-economic). For supporting activities in the program, the community still considers it not according to the needs or desires of the community. The existing activities are not in accordance with the needs of the community where the community wants more institutional training and market management activities, while what has been obtained so far is more on forestry cultivation techniques (such as nurseries, fertilizing, maintenance, etc).

In addition, the implementation time of activities was also generalized in each village that received the program. Even though each region has a different topography. The approach that has been used is the dominant top-down approach. Suhendra (2006) states that the activities aimed at to empower the community there is often a bias because Topdown planning, namely development planning in the village is designed from the center. So that the planning carried out at the center will be carried out for all regions equally by preparing technical implementation instructions.

Community participation is a major aspect of community empowerment. High or low community participation will determine the success of a program and activity. Participation in the development of private forests in Malang regency is still low. In addition, in the program formulation process, forest farmer groups have not yet been involved. When the community is not involved in planning (the initial process) the community feels less responsible. To increase the participation of private forest management groups by using a personal approach undertaken by assistants both from experts and assistants from Community Forestry Extension Workers (PKSM).

To support the private forest development program based on community empowerment this can be sustainable (not only when the project is in progress) so collaborative efforts are needed with the private sector. But this is still an obstacle in Malang Regency. Cooperation efforts in the field of forestry between forestry stakeholders have not yet been carried out clearly. The output of private forest development programs that can only be felt by the community after 5 years affects the motivation, community participation and the private sector to invest their capital. For this reason cross-sectoral coordination is needed under the facilitation of the Development Planning Agency (Provincial and District) or the appropriate agency because there are still very few companies willing to allocate CSR programs or funds to assist forestry development.

Aspects of linkages in empowerment are very important, linkages can be seen from policies and strategies at the local, regional and national levels (Drijver and Sajise, 1993). Private forest development programs based on community empowerment are an integral part of national development so that they cannot be separated from national development plans. The linkage of private forest development programs based on community empowerment with the planning documents on it are as follows in Figure 2.

Private forest development program based on community empowerment also refers to policies made by the Central Government and the Provincial Government. In addition, in private forest development programs based on community empowerment also related to the global development paradigm, namely Sustainable Development Goals (SDGs) and Reducing Emissions from Deforestation and Forest Degradation (REDD+). With the development of private forests it is expected to achieve the Sustainable Development Goals 
(SDGs) target, namely the problem of forest area cover to deal with climate change. If seen in the 2014-2019 National Medium-Term Development Plan (RPJMN), one of the strategic issues that must be addressed immediately is the problem of forest destruction. One of the main targets of forestry development in the 2014-2019 RPJMN is to increase the area of private forest. Forestry development strategy in the Regional Medium-Term Development Plan (RPJMD) which emphasizes the active involvement of the community in forestry development through the process of community empowerment.

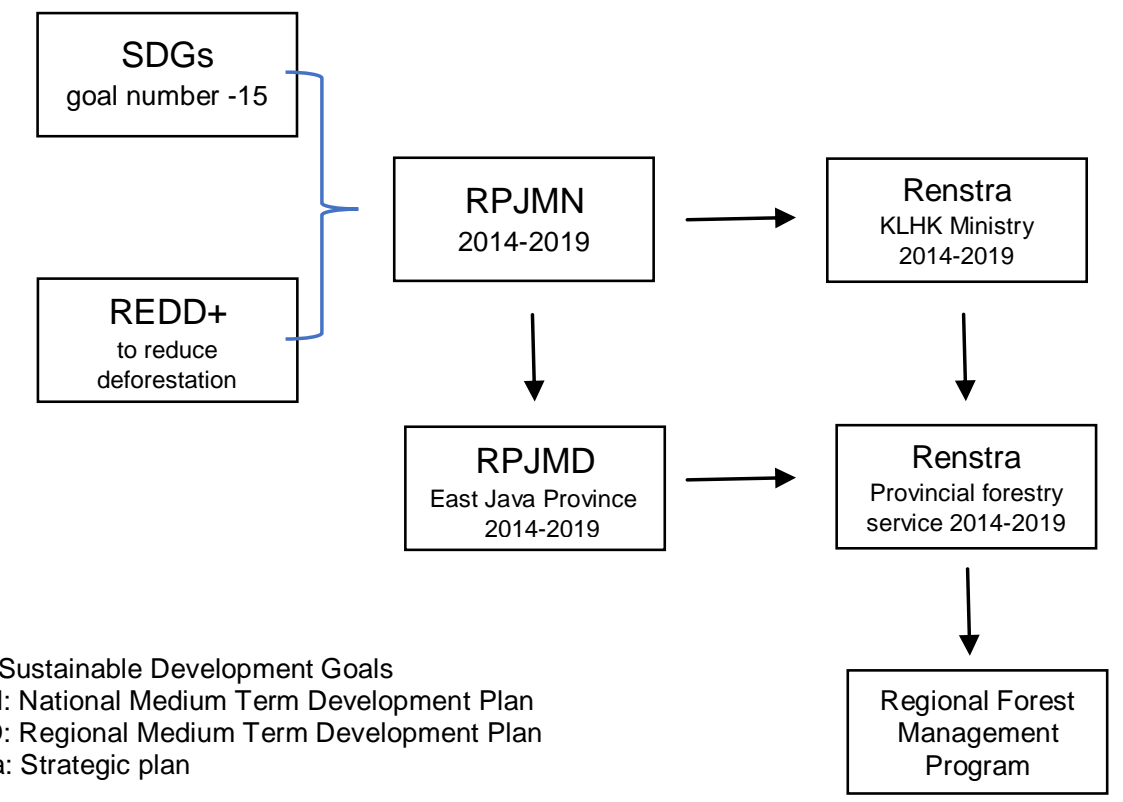

Figure 2 - Linkages from regional forest management program (Data Processed, 2019)

Social and economic benefits must be considered in planning community empowerment based programs. The activities of village seedlings garden, enrichment of private forests and agroforestry development has provided many benefits both in terms of social, economic, and environmental. From the social aspect, community participation can be built in protecting the environment. In the economic side, the economy of the community will improve because they do not need to spend a lot of money in nurseries. While from the environmental aspect, the presence of forestry plants can prevent their environment from disasters such as floods and landslides.

Community empowerment efforts can be done through institutional development, facility development, and counseling development, assistance, and service Zubaedi (2007). For this reason, development programs must be carried out through these empowerment efforts. The private forest management group institutionalization in Malang Regency is still weak. Community participation is still low and the extension activities are mostly technical in forestry. The success of forestry development can be achieved by building capacity. To achieve success in capacity building it requires the participation of local communities in forest management activities and sharing of responsibilities in forest management (Pujo, et al., 2018). The local community must be involved in deciding which activities to develop to achieve a proper forest management system in economic terms, can adapt socially, and environmentally friendly. The capacity of local organizations refers to the ability of communities to work together, organize them, and mobilize resources to solve problems (Narayan, 2002).

The development of facilities carried out by the Malang Region CDK is in the form the development of Forest and Land Rehabilitation ( $\mathrm{RHL}$ ) technology which aims to increase the support of planning, implementing and monitoring technology. The development of forest and land rehabilitation in the implementation includes methods and techniques in carrying out rehabilitation activities, including in nurseries, planting, and building soil conservation 
buildings, maintenance, protection and security. Not yet optimal application of information technology (data bases) in the presentation of information or promotion in the field of forestry is often complained of by farmers. Market access or marketing of forest products is still very limited, also caused by minimal information reaching the community related to the marketing of forest products.

Forestry extension activities are one of the spearheads of private forest development in Malang Regency, which is inseparable from the role of field workers or extension agents. However, community empowerment in Malang Regency is still constrained by the limited number of field extension workers. The performance of forestry instructors is still not optimal because it only focuses on technical matters and sometimes feels boring. Even so, the existence of forestry extension can be beneficial because it can overcome technical forestry problems. In addition, in terms of apparatus resources, the quality and quantity of existing human resources is still not competitive in the CDK in Malang, the performance of administrative, financial and forest engineering aspects has not been optimal. Coordination in the process of gathering data and information on forestry development has not been optimal. This condition is caused by the commitment of data and information processing officers in updating data which is still not optimal.

\section{CONCLUSION}

For supporting activities in the program, the community still considers it not according to the needs or desires of the community. This is because the community is not involved in the formulation process. The planning of private forest development in Malang which is dominated by the top down approach needs to be balanced with the bottom up approach. This causes the efforts of community empowerment in the development of private forests in Malang Regency not yet optimal. To increase the participation of private forest farmer groups, it can be done by using a personal approach through mentors from experts and assistants from the Community Forestry Extension Workers (PKSM). Additionally in community empowerment in Malang also required the addition of the quality and quantity of human resources experienced field personnel as facilitators through the development of forest management.

\section{REFERENCES}

1. Badan Pusat Statistik. 2015. Potret Awal Pembangunan Pasca MDGs, Sustainable Development Goals SDGs. Jakarta: BPS.

2. Dinas Kehutanan Provinsi Jawa Timur. 2018. Kehutanan Dalam Angka Provinsi Jawa Timur Tahun 2013 - 2017: Sidoarjo: Dishut Jatim.

3. Drijver, C. and Sajise, P. "Community-Based Resource Management and Environmental Action Research". Proceedings of the Experts' Workshop on Community Based Resource Management: Perspectives, Experiences and Policy Issues, Philippines: Los Banos, Environmental and Resource Management Project and UPLB.

4. Miles, M.B. 2014. Qualitative Data Analysis, Methods Sourcebook. Sage Publications.

5. Narayan, Deepa. 2002. Empowerment and Poverty Reduction. The World Bank.

6. Pujo. 2018. Community Capacity Building in Social Forestry Development: A Review. Journal of Regional and City Planning, 29(2), 113-126.

7. Rencana Pembangunan Jangka Menengah Nasional Tahun 2014-2019.

8. Rencana Kerja Cabang Dinas Kehutanan Wilayah Malang Tahun 2018-2019.

9. Rencana Kerja Dinas Kehutanan Provinsi Jawa Timur Tahun 2018.

10. Rencana Strategis Dinas Kehutanan Provinsi Jawa Timur Tahun 2014-2019 Perubahan.

11. Sugiyono, 2014. Memahami Penelitian Kualitatif. Bandung: Alfabeta.

12. Suhendra, K. 2006. Peranan Birokrasi Dalam Pemberdayaan Masyarakat. Alfabeta.

13. Sulistiyani, Ambar Teguh. 2004. Kemitraan and Model - Model Pemberdayaan. Gava.

14. Zubaedi. 2007. Wacana Pembangunan Alternatif: Ragam Perspektif Pengembangan and Pemberdayaan Masyarakat. Jogjakarta: Ar-Ruzz Media. 